\title{
Role of Technical Teachers in Public Relations towards Optimizing Students' Enrollment in Technical and Vocational Education Training in Nigeria
}

\author{
Gowon Kerter Eric ${ }^{1} \&$ Auta Mohammed Adamu ${ }^{2} \&$ Ibeneme Ogochukwu ${ }^{3}$
}

\author{
${ }^{1}$ Department of Technology Education, School of Technology and Science Education, Modibbo Adama \\ University of Technology, Yola, Adamawa State, Nigeria \\ ${ }^{2 \& 3}$ Department of Technology and Vocational Education, Faculty of Education, Nnamdi Azikiwe \\ University Awka, Anambra State, Nigeria \\ Corresponcence: Gowon Kerter Eric, Modibbo Adama University of Technology, Yola, Adamawa \\ State, Nigeria. Email: ericgowon@gmail.com
}

Received: April 10, 2019

Accepted: May 25, 2019

Online Published: June 1, 2019

doi: 10.23918/ijsses.v5i4p140

\begin{abstract}
This study was undertaken to investigate the role of technical teachers in public relations towards optimizing students' enrolment in TVET programmes in Nigeria. Two specific objectives and corresponding research questions were generated with a null hypothesis formulated respectively to guide the study. Descriptive survey design approach was adopted for the study. A 30 item questionnaire structured in a five point rating scale was used to collect data for the study. The instrument was face validated by three experts and a reliability coefficient of 0.79 was obtained with Cronbach's Alpha coefficient method. The population of this study was 216 respondents made up of 36 technical teachers teaching in the three Government Science and Technical Colleges, Federal Science and Technical Colleges and a Vocational Centre within the study area, 180 NTC III and NVC III students of the colleges/centre. The population for this study was manageable; hence, there was no sampling and sampling techniques in this study. The entire population was used as sample in the study. Data were analyzed using mean and standard deviation to answer the research questions, while z-test statistics was used to test the hypothesis at 0.05 level of significance. The findings of this study revealed among others the public relation activities practiced by technical teachers in Adamawa State colleges/centre such as; granting audience to the press on TVET programmes; creating awareness of TVET through community organizations, reaching parents through newsletter and contacts of technical teachers with alumni members. Strategies such as technical teachers visiting religious and social gathering to create public awareness on the need for TVET enrollment with gender equity, exhibits departmental work displayed at stores, fairs and festivals were revealed as those public relation role which technical teachers can play to improve students' enrollment. Consequently, it was recommended among others that technical teachers should be actively involved in public relations activities to inform the school and the larger community on the career viability of the range of TVET programmes offered, so men and women can make informed vocational selection.
\end{abstract}

Keywords: Technical Teachers, TVET, Public Relations, Adamawa State

\section{Introduction}

Student's enrollment into technical and vocational education and training has become an issue of concern to all educational stakeholders. This is because of its potentials in the reduction of employment rate in every nation through skilled training that leads to self-reliance. According to Tika (2015), formal system of education placed less emphasis on vocational and technical skills and the knowledge falls 
short of the developmental needs of Nigeria. The nation had no option but to embrace technical and vocational education. Owning to the current economic atmosphere as observed in most developed countries in the world today, TVET is expected to produce and supply intermediate craftsmen, technicians, semi-skilled and skilled manpower that will be capable to function very well in all sectors in the industry critical to national development, Okeke cited in Okwelle (2010) and Okolocha (2006) noted that since the introduction of TVET in Nigeria education system some decades ago, enrolment in TVET programme in Nigeria has remain squat. This ugly situation can be attributed to bad stereotype on TVET among other poor or rather wrong public perceptions. This development according to Agwi and Puyate (2017) is more disturbing on female students' participation in TVET programme in Nigeria. Ukachukwu (2015) also stated that this development has posed inherent danger to technology education and national development. In line with this view, Uzougwu (2014) reported that the total enrolment figure into TVET programme in Nigeria as at 2014 was less than five percent of the population. Uzougwu further noted that this figure, in comparison with countries seeking to have rapid socio-economic development is negligible as these countries target about fifty percent enrolment annually. Especially in a nation like Nigeria where technology is borrowed, there is high need for technical skilled man-power to assemble, install, and maintain the available technology.

Different scholars such as Durujaye, Ajie and Aiyegbusi (2014); Bloor (2001) have identified major reasons responsible for the low enrolment of students in TVET to include among others, low societal estimation of TVET as education for low class people, education for the last resort for people of low intelligent - quotient, low achievers, socio-economic issues and low status occupation as well as lack of career awareness in TVET. The effect of this low enrolment of students especially the female students as observed by researchers in technical vocational education and training programmes in particular, is that many post primary schools in the country lack the quality and quantity of technical teachers for implementing the technology education programmes at this level of education relevant to national development (Okwelle, 2011). The current reform of technical vocational education and training (TVET) system in Nigeria seems to have not fully addressed the impediments to technology education development in the country till date. There is therefore the need to further intensity efforts geared towards repositioning (TVET) institutions with a view to making them attractive to prospective students. It is in line with this fact that several studies (Agwi, 2016; Okwelle \& Ibeneme, 2008; Okwori, 2011), have identified some sustainable strategies of enhancing students enrolment in TVET programmes. Some of these strategies according to these authors are organizing regular excursion for TVET students, recognizing/rewarding outstanding student achievement through awards, commendation and introducing public relations activities into the school curriculum. The poor enrollment is most alarming on the part of female students. This situation is predominantly caused by societal constructs which limits the enrollment of the girl child into TVET programmes.

According to Afeti and Ayélé (2013) having 50\% of a country's population participating in subpar/subsistence work is detrimental to the economic development of a nation. Equally important, it is detrimental to the individual girl or woman, who is denied access to opportunities to develop her fullest potential. Given the TVET's potential to improve access to sustainable livelihoods and women's particular vulnerability in accessing employment opportunities, it is imperative to facilitate their access to and participation in TVET. In doing so, they may gain relevant, practical, market-driven skills and improve their livelihoods. However, differential access to education is also evident in TVET. These 
include: limited access to TVET training, limited range of vocations for those women who do receive training, low technical level of training offered, and lack of social support (UNESCO, 2013). These limitations can be surmounted with effective public relations by the technical teachers. Effectual PR by teacher can create a synergy among the community, industries and the school programme with the goals of understanding the goings-on towards of improving the programme.

Technical teachers are the driving force of this great goal for the development of the nation. Technical teachers are generally refer to teachers of vocational subjects, such as electronics, construction or mechanical, agriculture and many other related trades. The framework can, however, be used for teachers of common core subjects such as languages, mathematics or science. The latter types of teachers are commonly thought of as experts only in their own subject matter without a connection to the vocational fields.

As pedagogues at science and technical colleges, the teacher gets the unique chance to promote the public's perceptions of the world and human life holistically: During the apprenticeship at a training centre, college or at the company. Combining these three locations effectively, the teacher can offer the students utmost possibilities of experiences in professional knowledge (Agwi, 2016). In other countries the so called "dual system" as a strategic network between company or corporation, vocational college and vocational training centre ensures apprenticeships, which benefit from shared tasks respecting such participant's abilities.

Technical and Vocational Education Training relies to the close cooperation of optimized use of resources for the students: Each partner in the "dual system" contributes a secure part of the education, fixed in curricula, handcraft acquisition plans, and additional vocational trainings (Uzougwu, 2014). This can only be achieved efficiently through employing public relation movement. According to Okwori (2011) public relations in the contest of educational process are defined as a planned and systematic management function to help improve the programmes and services of an education system.

It seems imperative that the student's enrollment, which is a matter of serious concern in the heart of Nigeria vocational education and training system, be restructured to enhance massive enrollment with gender equity. This study has identified a knowledge gap indicating the need to investigate the role of technical teachers in public relations towards optimizing students' enrolment in TVET programmes, with focal attention on community involvement through the public relations.

\section{Purpose of the Study}

The main purpose of this study was to investigate the role of technical teachers in public relations towards optimizing students' enrolment in TVET programmes in Nigeria. Specifically the study intends to:

1. Identify the public relation activities practice by technical teachers in Adamawa State colleges/centre.

2. Suggest specific roles by technical teachers in public relations towards optimizing students' enrolment in TVET programmes. 


\section{Research Questions}

The following research questions were posed to guide the study:

1. What are the public relation activities practiced by technical teachers in Adamawa State colleges/centre?

2. What are the specific roles by technical teachers in public relations towards optimizing students' enrolment in TVET programmes?

\section{Hypothesis}

One null hypothesis was formulated to guide the study and was tested at 0.05 level of significance:

$\mathrm{HO}_{1}$ : There is no significant difference between the mean responses of male technical teachers/students and female technical teachers/students on the specific roles by technical teachers in public relations towards optimizing students' enrolment in TVET programmes.

\section{Methodology}

Survey research design was adopted for the study. The study was carried out in Adamawa State which is located in the North-East region of Nigeria, with a geographical coordinates of $9^{\circ} 20^{\prime}$ North, $12^{\circ} 30^{\prime}$ East and a land mass of about 39, 742, $12 \mathrm{~km}^{2}$ (Adebayo \& Tukur, 1999). The population of this study was 216 respondents made up of 36 technical teachers teaching in the three Government Science and Technical Colleges, Federal Science and Technical Colleges and a Vocational Centre, 180 NTC III and NVC III students of the colleges/centre. The population for this study was manageable hence, there was no sampling and sampling techniques in this study. The entire population was used as sample in the study. A 30-item structured questionnaire developed by the researchers titled "Role of Technical Teachers in Public Relations towards Optimizing Students' Enrolment in TVET Programmes in Adamawa State" (RTTPROSETPAS)" was used for data collection. The instrument was validated by three experts in Technology Education Department, Modibbo Adama University of Technology, Yola. The instrument was trial tested using 5 respondents from a technical college that is not part of the sampled population. The data collected was analyzed using Cronbach Alpha Correlation Co-efficient which yielded 0.79 . The coefficient indicated high internal consistency which proved that the instrument was reliable to be used for the study. The data collected were analyzed using simple descriptive statistics of mean and standard deviation to answer research questions whereby a mean cut-off point of 3.50 was used for decision making. Any mean score of 3.50 and above was agreed upon while any mean score below 3.50 was disagreed upon. The research hypothesis was tested using z-Test at 0.05 level of significance.

\section{Results}

\subsection{Research Question 1}

What are the public relation activities practiced by technical teachers in Adamawa State colleges/centre? 
Table 1: Mean Rating and Standard Deviation of Responses on Public Relation Activities Practiced by Technical teachers in adamawa state colleges/centre

\begin{tabular}{llcccccc}
\hline S/N & Items & $\bar{X}_{1}$ & $\bar{X}_{2}$ & $\bar{X}_{G}$ & $\sigma$ & REMARK \\
\hline 1 & $\begin{array}{l}\text { Organized TVET exhibition programmes during } \\
\text { speech and price giving days }\end{array}$ & 3.41 & 2.98 & 3.35 & 0.44 & Disagreed \\
2 & $\begin{array}{l}\text { Sensitizing the public about the activities of TVET } \\
\text { programmes through newsletters }\end{array}$ & 3.12 & 3.11 & 3.13 & 0.32 & Disagreed \\
3 & $\begin{array}{l}\text { Granting audience to the press on TVET } \\
\text { programmes }\end{array}$ & 3.70 & 3.94 & 3.82 & 0.36 & Agreed \\
4 & $\begin{array}{l}\text { Technical teachers creating awareness of TVET to } \\
\text { the community organizations }\end{array}$ & 3.82 & 3.42 & 3.76 & 0.50 & Agreed \\
5 & $\begin{array}{l}\text { Public relations contact of technical teachers with } \\
\text { business and industry }\end{array}$ & 3.57 & 3.04 & 3.49 & 0.40 & Disagreed \\
6 & $\begin{array}{l}\text { Technical teachers reaching parents through } \\
\text { newsletter }\end{array}$ & 4.11 & 3.76 & 3.94 & 0.29 & Agreed \\
7 & $\begin{array}{l}\text { Technical teachers having open talk-show with basic } \\
\text { school pupils }\end{array}$ & 3.57 & 3.20 & 3.52 & 0.45 & Agreed \\
8 & $\begin{array}{l}\text { Public relation contacts of technical teachers with } \\
\text { alumni }\end{array}$ & 3.57 & 3.38 & 3.55 & 0.42 & Agreed \\
9 & $\begin{array}{l}\text { Technical teachers making publicity for TVET using } \\
\text { different media outlets }\end{array}$ & 3.48 & 2.96 & 3.54 & 0.41 & Agreed \\
Technical teachers using school guidance personnel & 2.96 & 3.00 & 2.98 & 0.34 & Disagreed \\
to improve enrollment in TVET programmes & Grand mean & 3.53 & 3.28 & 3.51 & 0.39 & Disagreed \\
\hline
\end{tabular}

Key: $\overline{\boldsymbol{X}}_{\mathbf{1}}=$ mean rating of teachers, $\overline{\boldsymbol{X}}_{\mathbf{2}}=$ mean rating of students, $\overline{\boldsymbol{X}}_{\boldsymbol{G}}=$ Item mean, $\sigma$ =standard deviation

Table 1 showed the summary of the result for research question one which reveals that both the students and teachers agreed on the six items $(3,4,6,7,8,9)$ as public relation activities practice by technical teachers in Adamawa State colleges/centre. It can be deduced that the other four items which had mean responses less than the 3.50 cut-off point were not accepted as public relation activities practiced. The standard deviation of below 1.00 for all responses from the individual groups of respondents indicates that the responses were closely unanimous. The grand mean of the two groups shows a mean of 3.51. Based on the data presented and the subsequent analysis, the respondents agreed on the public relation activities practice by technical teachers in Adamawa State colleges/centre. Some of those activities are; granting audience to the press on TVET programmes; creating awareness of TVET through community organizations, reaching parents through newsletter and contacts of technical teachers with alumni members.

\subsection{Research Question 2}

What are the specific roles by technical teachers in public relations towards optimizing students' enrolment in TVET programmes? 
Table 2: Mean ratings and standard deviations of respondents on the roles by technical teachers in public relations towards optimizing students' enrolment in TVET programmes

\begin{tabular}{|c|c|c|c|c|c|c|}
\hline $\mathrm{S} / \mathrm{N}$ & $\mathrm{N}_{1}=91, \mathrm{~N}_{2}=15$ & $\overline{\bar{X}_{1}}$ & $\overline{\bar{X}_{2}}$ & $\bar{X}_{G}$ & $\sigma$ & REMARK \\
\hline 11 & $\begin{array}{l}\text { Publications on the need for TVET programmes } \\
\text { that will produce skilled manpower }\end{array}$ & 3.52 & 4.42 & 3.97 & 0.41 & Agreed \\
\hline 12 & $\begin{array}{l}\text { Technical teachers making job analyses through } \\
\text { available media outlets }\end{array}$ & 4.70 & 4.36 & 4.65 & 0.48 & Agreed \\
\hline 13 & $\begin{array}{l}\text { Technical teachers engaging and participating in } \\
\text { community councils, forums and school planning } \\
\text { for TVET programmes. }\end{array}$ & 3.67 & 3.40 & 3.64 & 0.46 & Agreed \\
\hline 14 & $\begin{array}{l}\text { Technical teachers engagement and participation } \\
\text { in civic service club activities such as Civitan, } \\
\text { Rotary, Kiwanis, Lions among others } \\
\text { enlightening people on the significance of TVET } \\
\text { programmes. }\end{array}$ & 3.25 & 3.44 & 3.29 & 0.37 & Disagreed \\
\hline 15 & $\begin{array}{l}\text { Technical teachers visiting religious and social } \\
\text { gathering to create public awareness on the need } \\
\text { for TVET enrollment with gender equity }\end{array}$ & 4.51 & 4.64 & 4.55 & 0.41 & Agreed \\
\hline 16 & $\begin{array}{l}\text { Technical teachers serving as speakers or } \\
\text { consultant for career exploration classes }\end{array}$ & 2.64 & 3.73 & 2.84 & 0.24 & Disagreed \\
\hline 17 & $\begin{array}{l}\text { Providing information on prospective students } \\
\text { about the TVET programmes through interviews, } \\
\text { conferences or direct mail }\end{array}$ & 3.57 & 3.64 & 3.59 & 0.39 & Agreed \\
\hline 18 & $\begin{array}{l}\text { Technical teachers as assembly guest speak on } \\
\text { students enrollment into TVET programmes }\end{array}$ & 2.47 & 3.58 & 2.67 & 0.19 & Disagreed \\
\hline 19 & $\begin{array}{l}\text { Bulletins and informational reports sent to parents } \\
\text { concerning the school programmes in TVET }\end{array}$ & 3.15 & 3.31 & 3.19 & 0.30 & Disagreed \\
\hline 20 & $\begin{array}{l}\text { Technical teachers encouraging product } \\
\text { exhibitions to showcase the rich value of TVET } \\
\text { progammes to the public }\end{array}$ & 3.41 & 2.98 & 3.35 & 0.44 & Disagreed \\
\hline 21 & $\begin{array}{l}\text { Joint programmes (secondary schools with } \\
\text { technical colleges or vocational centres) where } \\
\text { public relational activities will be carried out. }\end{array}$ & 3.12 & 3.11 & 3.13 & 0.32 & Disagreed \\
\hline 22 & $\begin{array}{l}\text { Furnishing departmental publications and reports } \\
\text { to the public about the curricula, equipment and } \\
\text { personnel for improve enrollment }\end{array}$ & 3.20 & 3.44 & 3.26 & 0.36 & Disagreed \\
\hline 23 & $\begin{array}{l}\text { School year book containing sales, advertisement } \\
\text { and TVET content handled by students }\end{array}$ & 3.82 & 3.42 & 3.76 & 0.50 & Agreed \\
\hline 24 & $\begin{array}{l}\text { School newspaper including news of TVET } \\
\text { programmes and students' prospects }\end{array}$ & 3.57 & 4.04 & 3.81 & 0.40 & Agreed \\
\hline 25 & $\begin{array}{l}\text { Exhibits departmental work displayed at stores, } \\
\text { fairs and festivals }\end{array}$ & 3.91 & 4.47 & 3.15 & 0.29 & Agreed \\
\hline
\end{tabular}




\begin{tabular}{lllllll}
\hline 26 & $\begin{array}{l}\text { School news section of community newspaper } \\
\text { featuring TVET programmes activities such as } \\
\text { class work and materials and equipment used in } \\
\text { classes }\end{array}$ & 3.20 & 3.52 & 0.45 & Agreed \\
27 & $\begin{array}{l}\text { Career or TVET week where outside speakers } \\
\text { discuss job opportunities. }\end{array}$ & 3.57 & 3.38 & 3.55 & 0.42 & Agreed \\
28 & $\begin{array}{l}\text { School assemblies depicting TVET programmes } \\
\text { for instances plays illustrating business situations } \\
29\end{array}$ & 3.48 & 2.96 & 3.54 & 0.41 & Agreed \\
$\begin{array}{l}\text { Technical teachers reaching out via } \\
\text { demonstration by TVET students to improve } \\
\text { students' enrollment } 3.67\end{array}$ & 3.40 & 3.64 & 0.46 & Agreed \\
30 & $\begin{array}{l}\text { Evaluating TVET students work through report } \\
\text { card, letters, parent-teacher conferences, PTA } \\
\text { meetings. }\end{array}$ & 3.23 & 3.51 & 3.29 & 0.31 & Disagreed \\
Grand mean & 3.620 & 3.51 & 0.32 & Agreed \\
\hline
\end{tabular}

Key: $\overline{\boldsymbol{X}}_{1}=$ mean rating of teachers, $\overline{\boldsymbol{X}}_{2}=$ mean rating of students, $\overline{\boldsymbol{X}}_{G}=$ Item mean, $\sigma=$ standard deviation

The result in Table 2 above revealed that twelve (12) items were agreed upon by teachers and students as specific roles by technical teachers in public relations towards optimizing students' enrolment in TVET programmes. Whereas, eight other items from the list of twenty suggested were disagreed upon. The standard deviation of two groups of the respondents showed close but different ranges with each having a standard deviation below 0.48 which indicates that the responses of the respondents were closely related to each other. Since the grand mean of both responses is 3.51 , which is above the decision cut-off points, it means that the suggested strategies are good as specific roles by technical teachers in public relations towards optimizing students' enrolment in TVET programmes.

\subsection{Hypothesis 1}

There is no significant difference between the mean responses of technical teachers and students on the specific roles by technical teachers in public relations towards optimizing students' enrolment in TVET programmes.

Table 3: z-Test analysis of difference between opinion of technical teachers and students on the specific roles by technical teachers in public relations

\begin{tabular}{|c|c|c|c|c|c|c|}
\hline Respondents & $\mathrm{N}$ & $X$ & $\mathrm{~S}^{2}$ & $\overline{\text { z-cal }}$ & Z-crit & Remarks \\
\hline \multirow{2}{*}{ Technical Teachers } & 220 & 3.38 & 0.07 & & & \\
\hline & & & & 1.95 & 1.96 & Not Significant \\
\hline Students & 45 & 3.18 & 0.04 & & & \\
\hline Total & 265 & & & & & \\
\hline
\end{tabular}

Table 3 above revealed that $\mathrm{z}$-cal is 1.95 and is less than the z-crit of 1.96 at 0.05 level of significance. 
Hence, the null hypothesis was accepted indicating that there is no significant difference between the mean responses of teachers and students on public relations towards optimizing students' enrolment in TVET programmes.

\section{Discussion}

The result of the study revealed some of the public relation activities practiced by technical teachers in Adamawa State colleges/centre as; granting audience to the press on TVET programmes; creating awareness of TVET through community organizations, reaching parents through newsletter and contacts of technical teachers with alumni members.

Findings of the study revealed that the suggested strategies are good as specific roles by technical teachers in public relations towards optimizing students' enrolment in TVET programmes. Strategies such as technical teachers visiting religious and social gathering to create public awareness on the need for TVET enrollment with gender equity, exhibits departmental work displayed at stores, fairs and festivals. Others are career or TVET week where outside speakers discuss job opportunities, school year book containing sales, advertisement and TVET content handled by students, school assemblies depicting TVET programmes for instances plays illustrating business situations and school news section of community newspaper featuring TVET programmes activities such as class work and materials and equipment used in classes. This finding is in consonance with findings of different scholarly works which have identified some sustainable strategies of enhancing students' enrolment in TVET programmes. Some of these strategies according to these authors (Okwelle \& Ibeneme, 2008; Okwori, 2011) are organizing regular excursion for TVET students, recognizing/rewarding outstanding student achievement through awards, commendation and introducing public relations activities into the school curriculum. The poor enrollment is most alarming on the part of female students. This situation is predominantly caused by societal constructs will limits the enrollment of the girl child into TVET programmes. The study revealed that there is no significant difference between the mean responses of teachers and students on public relations towards optimizing students' enrolment in TVET programmes.

\section{Conclusion and Recommendations}

Based on findings of the study, it is concluded that school public relations is a significant tool for enhancing students enrollment in TVET programmes which in turn will create skilled manpower. With the school public relations, technical teachers can reach out to the stakeholder, parents, community and the larger society to rewrite the wrong perception on technical schools. In Nigeria there has been a stereotype of perceiving technical college students or craftsmen as the academically weak. This situation can only be averted with the effective and practically involvement of technical teachers and students in public relations activities. In order to address these differences and optimize students' enrollment into TVET programmes, there is a critical need for:

1. Technical teachers should be actively involved in public relations activities to inform the school and the larger community on the career viability of the range of TVET programmes offered, so men and women can make informed vocational selection. 
2. The Ministry of Education and other relevant stakeholders should encourage participation of technical teachers in public relations toward improving students' enrollment with consideration to gender equity CAin TVET programmes.

\section{References}

Afeti, G. \& Ayélé L. A. (2013). Lifelong technical and vocational skills development for sustainable socioeconomic growth in Africa.

Agwi, V.I.A. \& Puyate, S.T. (2017). Strategies for improving female students enrolment in technical vocational education and training (TVET) programmes in Rivers and Bayelsa States. Journal of Education in Development Areas, 25(1), 65-80.

Agwi, V.I.A. (2016). Technical and Vocational education (VTE) programme in Nigeria: A useful means of acquiring better skills for self-employment. Journal of Advancement in Education, 10(1), 34-45.

Ajayi, K.O., Akinsanya, O. O., \& Agbajeola, R. O. (2011). Parental Role in Gender Stereotyping in Vocational Education in $21^{\text {st }}$ Century, Nigeria. Journal of Basic and Applied Scientific Research.

Durojaye, M.O., Ajie, I.O. \& Aiyegbusi, S.M. (2014). Improving the participation and performance of female students in science and technical education. International Journal of Research in Education, 3(2), 313-316.

Gaidzanwa, R. B. (2008). Gender Issues in Technical and Vocational Education and Training. Association for the Development of Education in Africa: Biennale on Education in Africa.

Ibeneme, O.T. \& Okwelle, P.C. (2008). Increasing tertiary institution students in school public relations for enhancing technical and vocational education (TVE) development in Nigeria. Orient Journal of Education, 4(2), 67-75.

International Labour Office (ILO) (2000). Conclusions on lifelong learning in the twenty-first century: The changing roles of educational personnel, Note on the Proceedings, Joint Meeting on Lifelong Learning in the Twenty-first Century, Geneva, 2000, JMEP/2000/10 (Geneva) page 34-35.

Okwelle, P.C. \& Ibeneme, O.T. (2008). Sustainable school public relations activities an imperative for improving enrolment into technical colleges in Nigeria. Trends in Education Studies (TRES), 3(1), 17-33.

Okwelle, P.C. \& Okeke, B.C. (2016). An overview of the role of technical vocational education and training (TVET) in nation development. African Journal of Historical Sciences in Education. 12(1), 16-32.

Okwelle, P.C. (2010). Strategies for improving enrolment into technical teacher education programmes through students' involvement in public relations activities. Niger Delta Journal of Education. 2(1\&2), 57-63.

Okwelle, P.C. (2011). Effective students involvement in public relations: A strategy for improving enrolment into technical teachers education programme. Journal of National Association of Teachers of Technology, 7(3), 13-28.

Okwori, R.O. (2011). Sustainable technical and vocational education through private agencies participation: A study of secondary schools in Okpokwu Local Government Area Benue State. Journal of Association of Teachers of Technology, 7(3), 48-52.

Tika, T.J. (2015). Assessment of the cognitive and psychomotor skills performance of students in bricklaying, blocklaying and concreting trade in technical colleges of Adamawa State. An Unpublished doctoral dissertation; department of Technology Education, Modibbo Adama University of Technology, Yola.

UNESCO (2013). Youth Version: Education for All Global Monitoring Report. http://portal.unesco.org/education/en/ev.php Retrieved $15^{\text {th }}$ July, 2018 
International Journal of Social Sciences \& Educational Studies ISSN 2520-0968 (Online), ISSN 2409-1294 (Print), June 2019, Vol.5, No.4

Uzougwu, C.B. (2014). Technical vocational education and training (TVET) in Nigeria: The way forward. Journal of Academic Excellence, 15(1), 41-59. 